\title{
Respons molekuler Hevea brasiliensis ethylene response factors (HbERFs) sebagai marka ekspresi gen terhadap stimulasi ethephon pada klon-klon tanaman karet
}

\author{
Moleculer response of Hevea brasiliensis ethylene response factors (HbERFs) as expression \\ marker genes in response to ethephon stimulation in rubber tree clones

\section{Riza Arief PUTRANTO ${ }^{1)}$, KUSWANHADI $^{2)} \&$ Pascal MONTORO $^{3)}$} \\ 1) Balai Penelitian Bioteknologi Perkebunan Indonesia, Jl. Taman Kencana No. 1, Bogor 16128, Indonesia \\ ${ }^{2)}$ Pusat Penelitian Karet, Jl. Salak No. 1, Bogor 16128, Indonesia \\ 3) Centre de Coopération Internationale en Recherche Agronomique pour le Développement, \\ Avenue d'Agropolis, Montpellier 34398, Prancis
}

Diterima tanggal 8 Oktober 2014/disetujui tanggal 30 Desember 2014

\begin{abstract}
Real-Time quantitative RT-PCR technique is a sensitive method for measuring the accumulation of gene transcripts. This widely used technique in a variety of plant species; including rubber tree (Hevea brasiliensis) must meet basic criteria in order to produce accurate gene expression markers. Gene expression markers associated to the response of ethephon stimulation such as the Hevea brasiliensis Ethylene Response Factors (HbERFs) family has been characterized in a single rubber clone. It is known that the effect of genotype on rubber tree clones can give different expression of the same gene. This difference can be converted into a profile that characterizes clones to a certain trait. This study aimed to identify gene expression profile in response to ethephon stimulation using six HbERFs (HbORA47, HbRAP2.3, HbERF12, HbERF3, HbABR1, HbRRTF1) in three rubber tree clones having contrasted latex metabolism (PB 260, SP 217, and RRIM 600). Total RNA was isolated from 18 samples and used for cDNA synthesis. The quality of cDNAs was examined by PCR using $\mathrm{HbActin}$ primer. HbRH2b was selected among the 11 housekeeping genes to be used as an internal control in gene expression analysis. Gene expression analysis resulted to an induction and inhibition of HbERFs by ethephon stimulation which are specific to a particular clone. Expression profile of three Hevea clones showed distinct characteristics. The high latex metabolism clone PB 260 was characterized by the upregulated expression of HbRAP2.3 and HbERF12. The low latex metabolism clone SP 217 was characterized by the upregulated expression of HbRAP2.3 and HbRRTF1. Meanwhile, the profile of intermediate latex metabolism clone RRIM 600 was shown by downregulated expression of HbORA47 and upregulated expression of $\mathrm{HbABR} 1$. This study shows that HbERFs gene family is an important expression marker because it can inform physiological conditions of rubber clones associated in response to ethephon.
\end{abstract}

[Keywords: Real-Time quantitative RT-PCR, expression profile, transcript accumulation, genotype effect, internal control].

*) Penulis korespondensi: rizaputranton@gamil.com

\begin{abstract}
Abstrak
Teknik Real-Time quantitative RT-PCR merupakan metode sensitif untuk mengukur akumulasi transkrip dari gen. Teknik yang telah banyak digunakan pada berbagai spesies tanaman, termasuk tanaman karet (Hevea brasiliensis) ini harus memenuhi kriteria dasar agar menghasilkan marka ekspresi gen yang akurat. Beberapa marka ekspresi gen terkait respons terhadap stimulasi ethephon seperti famili gen Hevea brasiliensis Ethylene Response Factors (HbERFs) telah dikarakterisasi pada satu klon tanaman karet. Sebagaimana diketahui, efek genotip pada klon tanaman karet dapat memberikan ekspresi yang berbeda dari gen yang sama. Perbedaan ekspresi tersebut dapat dikonversi menjadi sebuah profil yang menjadi karakteristik klon karet terhadap perlakuan tertentu. Penelitian ini bertujuan untuk mengidentifikasi profil ekspresi gen HbERFs pada tiga klon tanaman karet (PB 260, SP 217, dan RRIM 600) yang memiliki metabolisme lateks yang berbeda terhadap respons stimulasi ethephon dengan menggunakan enam gen HbERFs (HbORA47, HbRAP2.3, HbERF12, HbERF3, HbABR1, HbRRTF1). RNA total diisolasi dari 18 sampel dan digunakan untuk sintesis cDNA. Kualitas cDNA diperiksa dengan PCR menggunakan primer HbActin. Gen HbRH2b terseleksi diantara 11 gen housekeeping digunakan sebagai kontrol internal pada analisis ekspresi gen. Hasil dari analisis ekspresi gen menunjukkan bahwa stimulasi ethephon memiliki efek induksi dan inhibisi gen yang spesifik untuk klon tertentu. Profil ekspresi dari tiga klon tanaman karet yang diuji memperlihatkan perbedaan karakteristik. Klon metabolisme tinggi PB 260 ditunjukkan dengan ekspresi positif dari gen HbRAP2.3 dan HbERF12. Klon metabolisme rendah SP 217 ditunjukkan oleh ekspresi positif gen HbRAP2.3 dan HbRRTF1. Sedangkan klon metabolisme intermedier RRIM 600 memiliki profil ekspresi negatif dari HbORA47 dan ekspresi positif dari HbABR1. Penelitian ini memperlihatkan bahwa famili gen $H b E R F s$ merupakan marka ekspresi yang penting karena dapat menginformasikan kondisi fisiologis klon tanaman karet terkait respons terhadap ethephon.
\end{abstract}

[Kata kunci: Real-Time quantitative RT-PCR, profil ekspresi, akumulasi transkrip, efek genotip, kontrol internal]. 


\section{Pendahuluan}

Analisis ekspresi gen telah banyak digunakan untuk mengeksplorasi proses biologi. Melalui analisis ini, akumulasi mRNA diukur menggunakan metode yang cepat, sensitif, dan reliable. Saat ini, teknik PCR berbasis fluorescens seperti Real-Time quantitative Reverse Transcriptase PCR (Real Time qRT$P C R)$ merupakan metode yang paling dapat dihandalkan untuk mendeteksi kelimpahan mRNA bahkan dalam jumlah yang rendah (Ginzinger 2002; Udvardi et al., 2008). Karena keunggulannya dalam sensitivitas dan penggunaan untuk cakupan luas, Real-Time quantitative RT-PCR dapat digunakan untuk membandingkan mRNA yang berbeda kemelimpahannya dalam populasi sampel pada waktu tertentu (Rieu \& Powers 2009; Skern et al., 2005). Akan tetapi, keakuratan teknik tersebut sangat tergantung pada cara sampling, kualitas template dan efisiensi amplifikasi (Bustin et al., 2009). Kehandalan hasil Real-Time PCR juga sangat tergantung pada kontrol internal yang dipilih (Kozera \& Rapacz, 2013). Level ekspresi dari kontrol internal harus tetap konstan pada berbagai parameter eksperimental seperti perlakuan, organ atau jaringan sampel. Teknik analisis ekspresi gen ini telah banyak menghasilkan marka ekspresi gen yang penting dalam proses fisiologi terkait stres maupun perkembangan pada berbagai spesies tanaman (Zhao et al., 2014; Wang et al., 2014; Xiong et al., 2013).

Selama kurun waktu lima tahun terakhir, analisis ekspresi gen menggunakan teknik Real-Time qRT-PCR telah banyak dilakukan pada tanaman karet (Hevea brasiliensis Müll. Arg.), terutama yang terkait respon stres pada saat penyadapan lateks (Duan et al., 2010; Piyatrakul et al., 2014; Putranto et al., Submitted-a, Putranto et al., Submitted-b, Putranto et al., 2012; Qin et al., 2014, Xiao et al., 2014; Aoki et al., 2014). Hingga saat ini, H. brasiliensis merupakan satu-satunya sumber komersial lateks alam. Toleransi terhadap stres berulang yang diakibatkan oleh penyadapan lateks merupakan fenomena khas pada tanaman karet. Penyadapan lateks sendiri terdiri dari dua proses yaitu penyadapan panel batang tanaman karet dan stimulasi batang karet menggunakan bahan aktif pelepas etilen yang disebut ethephon. Beberapa penelitian telah membuktikan akan peran hormon etilen terkait aktivasi metabolisme latisifer untuk produksi lateks (Lacote et al., 2010; Zhu \& Zhang, 2009), dimana proses sinyalisasinya melibatkan famili gen yang dinamakan Ethylene Response Factors (ERFs). Ethylene Response Factors merupakan faktor transkripsi terakhir yang diketahui dalam jalur transduksi hormon etilen dan mengatur gen-gen downstream yang responsif terhadap etilen (Chen et al., 2005).
Famili gen tersebut telah diidentifikasi pada $H$. brasiliensis dan termasuk ke dalam superfamili AP2/ERF (APETALA2/Ethylene Response Factors) (Duan et al., 2013; Piyatrakul et al., 2014). Sebanyak 87 H. brasiliensis Ethylene Response Factors (HbERFs) telah dikarakterisasi dalam konteks biologis yang berbeda seperti proses embriogenesis somatik (Piyatrakul et al., 2012), diferensiasi latisifer (Wu et al., 2010), dan stres abiotik (Chen et al., 2012; Chen et al., 2011; Putranto et al., Submitted-a, Putranto et al., Submitted-b).

Hingga saat ini, analisis ekspresi gen yang telah dilakukan terhadap gen-gen $H b E R F s$ masih terbatas pada satu klon karet (PB 260) padahal diketahui bahwa gen yang sama tidak selalu diekspresikan dengan cara yang sama pada genotip yang berbeda (Bell et al., 2013). Ekspresi alel dari gen yang berasal dari tanaman induk (jantan dan betina) dapat memberikan fenotip yang berbeda dan membedakan genotip tanaman satu dengan yang lainnya (Guo et al., 2004; Miko, 2008). Pada tanaman karet, efek genotip tersebut sangat dikenal pada kasus studi penyakit Kering Alur Sadap (KAS) dimana toleransi terhadap KAS dikendalikan oleh genotip dari klonklon tanaman karet sesuai jenis metabolisme lateksnya yang dikenal sebagai tipologi klonal (Putranto et al., Submitted-a). Sebagai contoh, klon karet dengan kadar sukrosa tinggi dan fosfat inorganik rendah terindikasi memiliki metabolisme latisifer yang rendah dan potensi produksi lateks yang tinggi. Klon semacam ini memerlukan stimulasi ethephon untuk menginduksi metabolisme di dalam latisifer agar menghasilkan lateks seperti pada PB 217 (Eliathe et al., 2012). Sebaliknya, klon karet dengan kadar sukrosa rendah dan fosfat inorganik tinggi memiliki metabolisme aktif yang mengubah sukrosa menjadi cis-polyisopren (partikel karet) seperti PB 260 dan PB 235. Klon ini tidak memerlukan stimulasi ethephon untuk menginduksi metabolisme (Eliathe et al., 2012).

Di sisi lain, perbedaan ekspresi gen pada genotip yang berbeda dapat digunakan untuk identifikasi profil respons molekuler serta untuk mengetahui diversifikasi mekanisme metabolik dari genotip yang berbeda. Oleh karena itu, penelitian ini bertujuan untuk mengidentifikasi profil ekspresi gen $H b E R F s$ pada tiga klon karet dengan metabolisme lateks yang berbeda terhadap respons stimulasi ethephon. Optimasi teknik Real-Time $q R T-P C R$ dilakukan dengan melakukan validasi kualitas RNA dan cDNA, serta seleksi kontrol internal untuk normalisasi data ekspresi. Enam gen HbERFs (HbORA47, HbRAP2.3, HbERF12, HbERF3, HbABR1, HbRRTF1) digunakan dalam penelitian ini sebagai marka ekspresi gen untuk membedakan tiga klon yang diuji (PB 260, SP 217, dan RRIM 600). 


\section{Bahan dan Metode}

\section{Material tanaman}

Tamanan karet $(H$. brasiliensis) yang digunakan dalam penelitian ini terdiri dari klon PB 260, SP 217 , dan RRIM 600 berusia 8 tahun yang ditanam di Kebun Percobaan Balai Penelitian Karet Sembawa, Palembang. Klon-klon tersebut dipilih berdasarkan perbedaan sistem metabolisme lateks yang telah diuji : PB 260 (metabolisme tinggi), SP 217 (metabolisme rendah), dan RRIM 600 (metabolisme intermediate) (Putranto et al., Submitted-a). Total 18 pohon disadap setiap dua hari (perlakuan S2). Stimulasi ethephon (ET) dengan konsentrasi 2,5\% diaplikasikan pada kulit batang sebulan sekali selama satu tahun (perlakuan ET 12/y). Rancangan percobaan yang digunakan dalam penelitian ini adalah sebagai berikut : (1) 3 pohon dari klon PB 260 tanpa stimulasi ET; (2) 3 pohon dari klon PB 260 dengan stimulasi ET; (3) 3 pohon dari klon SP 217 tanpa stimulasi ET; (4) 3 pohon dari klon SP 217 dengan stimulasi ET; (5) 3 pohon dari klon RRIM 600 tanpa stimulasi ET; (6) 3 pohon dari klon RRIM 600 dengan stimulasi ET. Saat pengambilan sampel, batang karet disadap dengan potongan setengah spiral untuk melepaskan lateks. Dua puluh empat jam setelah stimulasi ET, sampel lateks dikumpulkan di dalam tabung berisi larutan bufer standar. Sampel disimpan dalam deep feezer dengan suhu $-80^{\circ} \mathrm{C}$ hingga isolasi RNA.

\section{Isolasi RNA dari lateks tanaman karet}

Total RNA diisolasi dari lateks dengan menggunakan metode cesium chloride cushion (Sambrook et al., 1989) yang telah dimodifikasi (Duan et al., 2010). Lateks dipisahkan dari larutan asam trikloroasetat $2.5 \%$ dengan menggunakan sentrifugasi pada $10.000 \mathrm{~g}$ selama 15 menit. Satu gram pelet lateks segar digiling menggunakan mortar dan dipindahkan ke dalam tabung berisi $30 \mathrm{~mL}$ bufer ekstraksi (guanidium isothiosianat $4 \mathrm{M}$, sarcosine $1 \%$, polivinilpirolidon $1 \%$, dan $ß$-merkaptoetanol 1\%). Setelah homogenisasi, tabung disimpan di es dan kemudian disentrifugasi dengan kecepatan $10.000 \mathrm{~g}$ pada suhu $4^{\circ} \mathrm{C}$ selama 30 menit. Supernatan dipindahkan ke tabung baru yang berisi $8 \mathrm{~mL} \mathrm{5,7} \mathrm{M}$ $\mathrm{CsCl}$. Ultra sentrifugasi dalam rotor tipe swing bucket dilakukan dengan kecepatan $89.705 \mathrm{~g}$ pada $20^{\circ} \mathrm{C}$ selama 20 jam. Supernatan dan cesium chloride dibuang sementara pelet RNA dicuci dengan etanol $70 \%$. Setelah dikeringanginkan selama 30 menit, pelet tersebut dilarutkan dalam $200 \mu \mathrm{L}$ nuclease-free water. Untuk menjamin kemurnian RNA, perlakuan DNase dilakukan dengan menggunakan kit TURBO ${ }^{T M}$ DNA-free (Ambion, USA). Konsentrasi dan kemurnian (rasio 260/280 nm) dari RNA diukur dengan menggunakan Infinite ${ }^{\circledR}$ 200PRO NanoQuant (Tecan Group Ltd, Swiss). Integritas RNA total diperiksa dengan elektroforesis. RNA kemudian disimpan pada $-80^{\circ} \mathrm{C}$ freezer.

\section{Seleksi pasangan primer spesifik}

Primer spesifik untuk mengamplifikasi gen-gen housekeeping dan Ethylene Response Factors (ERFs) pada $H$. brasiliensis $(H b E R F s)$ diseleksi berdasarkan penelitian-penelitian yang telah dilakukan sebelumnya. Keenam gen $H b E R F s$ dipilih berdasarkan hasil induksi tinggi terhadap respon ethephon pada klon PB 260 (Duan et al., 2013; Piyatrakul et al., 2012; Li et al., 2011a; Putranto et al., 2012). Pasangan primer tersebut disajikan pada Tabel 1. Perancangan primer telah mengikuti parameter standar untuk digunakan pada eksperimen Real-Time qPCR (Li et al., 2011b) dan telah dimodifikasi untuk mendapatkan spesifitas tinggi (Piyatrakul et al., 2012). Untuk memvalidasi kapasitas amplifikasi nyata dari pasangan primer yang didesain, efisiensi primer dihitung menggunakan analisis kurva standar (Putranto et al., 2012). Nilai efisiensi tersebut diperhitungkan dalam analisis ekspresi gen.

Sintesis cDNA dan reaksi untuk analisis Real-Time qRT-PCR

Sintesis utas pertama cDNA dilakukan menggunakan kit RevertAid ${ }^{T M} M-M u L V$ reverse transcriptase sesuai dengan protokol (MBI, Fermentas, Kanada). Kualitas cDNA diperiksa untuk setiap sampel dengan amplifikasi PCR menggunakan primer HbActin (Putranto et al., 2012). Analisis kuantitatif ekspresi gen dilakukan menggunakan mesin Real-Time qPCR Light Cycler 480 (Roche Applied Sciences, Swiss). Campuran reaksi PCR terdiri dari $2 \mu \mathrm{L}$ cDNA, $0.6 \mu \mathrm{L}$ masing-masing primer $5 \mu \mathrm{M}$, dan $3 \mu \mathrm{L} 2 X S Y B R$ Green PCR Master Mix (LightCycler® 480 SYBR Green I Master, Roche Applied Sciences) dalam volume total $6 \mu \mathrm{L}$. Kondisi reaksi PCR terdiri dari satu siklus denaturasi pada suhu $95^{\circ} \mathrm{C}$ selama 5 menit, diikuti dengan 45 siklus amplifikasi $\left(95^{\circ} \mathrm{C}\right.$ selama 20 detik, $60^{\circ} \mathrm{C}$ selama 15 detik, dan $72^{\circ} \mathrm{C}$ selama 20 detik) dan pendinginan pada suhu $4^{\circ} \mathrm{C}$ selama 30 detik. Spesifitas produk PCR divalidasi menggunakan melting curve tunggal.

Penentuan kontrol internal untuk analisis ekspresi gen menggunakan Real-Time qRT-PCR

Real-Time $q R T-P C R$ dilakukan pada sebelas gen housekeeping (HbelF1Aa, HbUBC4, HbUBC2b, HbYLS8, HbRH $2 b, H b R H 8, H b U B C 2 a, H b \alpha T u b$, Hb40S, HbUbi, dan HbActin) menggunakan total 18 sampel cDNA untuk memilih gen yang paling stabil sebagai kontrol internal dalam analisis ekspresi gen. Kesebelas gen tersebut terpilih berdasarkan hasil skrining dari data transkriptomik tanaman karet di CIRAD dan merupakan sebelas gen housekeeping 
yang dapat digunakan untuk analisis ekspresi gen (Piyatrakul et al. 2012). Nilai crossing-point (Cp) yaitu siklus dimana fluorensi menjadi terukur diatas ambang batas dari tiap gen ditentukan. Kontrol internal yang ideal dan dapat digunakan sebagai reference gene dalam analisis Real-Time $q P C R$ pada tanaman karet memiliki nilai rata-rata $\mathrm{Cp}$ berkisar pada siklus ke 20-25. Hal tersebut didasarkan pada penelitian pendahulu yang menunjukkan nilai $\mathrm{Cp}$ terbaik dari kontrol internal yang dapat digunakan untuk normalisasi data ekspresi gen (Duan et al., 2013; Piyatrakul et al., 2012; Li et al., 2011a; Putranto et al., 2012). Koefisien variasi yang menandakan variasi dalam populasi sampel dihitung dari standar deviasi (SD) tiap gen / rata-rata nilai $\mathrm{Cp}$ dari total sampel uji. Koefisien variasi yang mendekati nol menunjukkan rendahnya perbedaan $\mathrm{Cp}$ antar sampel yang berarti stabilnya ekspresi gen housekeeping tersebut dalam berbagai kondisi sampel. Gen housekeeping dengan koefisiensi variasi terendah akan dipilih sebagai kontrol internal.

Analisis ekspresi gen-gen HbERFs menggunakan Real-Time qRT-PCR

Enam gen $E R F$ yang digunakan dalam penelitian ini (HbORA47, HbRAP2.3, HbERF12, HbERF3, HbABR 1, HbRRTF1) merupakan marker ekspresi gen dalam penelitian ekspresi famili gen $H b E R F s$ spesifik pada sel latisifer penghasil lateks dimana fungsi putatifnya telah diprediksi. Secara berurutan gen tersebut memiliki nama lain yaitu $H b E R F-I I b 2$, HbERF-VIIa2O, HbERF-VIIIal3, HbERF-VIIIal4, HbERF-Xa8, HbERF-Xb1 (Piyatrakul et al. 2012). Jumlah akumulasi transkrip untuk setiap gen dihitung dengan normalisasi menggunakan akumulasi transkrip dari gen kontrol internal. Analisis tersebut juga memperhitungkan efisiensi primer. Perhitungan rasio normalisasi dari akumulasi transkrip dilakukan secara otomatis menggunakan Light Cycler Software versi 1.5.0 (Roche) menggunakan perhitungan sebagai berikut $:$ Rasio normalisasi $=$ Efisiensi primer $-\Delta(\mathrm{Cp}$ target-Cp kontrol internal terpilih). Data akhir ditampilkan dalam bentuk histogram.

\section{Analisis statistik untuk data ekspresi gen}

Nilai akumulasi transkrip gen merupakan rata-rata dari tiga ulangan biologis per perlakuan. Analisis statistik dilakukan setelah transformasi logaritmik dilakukan dari data ekspresi hasil Real-Time $q R T$ $P C R$. Analisis tersebut membandingkan akumulasi relatif transkrip enam gen HbERFs antara tanaman perlakuan (ethephon) dan kontrol (tanpa ethephon) pada tiga klon uji (PB 260, SP 217, dan RRIM 600) yang diuji menggunakan ANOVA diikuti dengan uji Newman-Keuls. Semua tes statistik dilakukan dengan menggunakan software XL-STAT (Addinsoft, AS).
Konstruksi profil marka ekspresi gen untuk klon karet

Data dari akumulasi transkrip gen setelah perlakuan ethephon ditransformasi menjadi kode warna berdasarkan upregulation atau downregulation dari setiap gen menggunakan program Cluster 3.0 (Stanford University, AS). Level ekspresi dihitung sebagai rasio antara nilai rata-rata akumulasi relatif transkrip antara tanaman perlakukan dan kontrol. Sebuah rasio $\geq 5.0$ dinyatakan upregulated dan ditandai dengan warna merah, sementara sebuah rasio $\leq 0,2$ dinyatakan downregulated dan ditandai dengan warna hijau.

\section{Hasil dan Pembahasan}

\section{Validasi integritas RNA dan sintesis cDNA}

Validasi integritas RNA merupakan tahapan awal yang penting dalam analisis ekspresi gen. Kualitas dan kuantitas RNA sangat menentukan pula kuantitas dan kualitas cDNA yang disintesis (Fleige \& Pfaffl 2006). Elektroforesis pada gel agarose menunjukkan bahwa RNA total hasil isolasi dari lateks tanaman karet bebas dari kontaminasi DNA (Gambar 1). Hasil pengukuran konsentrasi RNA menggunakan Nanoquant menunjukkan bahwa konsentrasi dan kemurnian seluruh sampel sesuai untuk analisis akumulasi transkrip dengan teknik Real-Time qRT$P C R$. Kemurnian RNA (rasio 260/280 nm) yang diperoleh berkisar antara 1.71-1.79 (Gambar 1). Sedangkan, konsentrasi RNA berkisar antara 141.52$205.36 \mathrm{ng} / \mu \mathrm{l}$ (data tidak ditampilkan). Salah satu cara untuk melakukan validasi integritas cDNA hasil reverse transcriptase adalah dengan menggunakan cDNA sebagai templat untuk amplifikasi PCR menggunakan primer dari salah satu gen housekeeping, seperti Actin (Putranto et al., 2012). Elektroforesis pada gel agarose menunjukkan bahwa 18 sampel cDNA tersebut memiliki kualitas yang baik, terlihat dari ketebalan band yang dihasilkan (Gambar 2). Reaksi PCR terbukti berjalan dengan baik dipastikan dengan teramplifikasinya gen HbActin dari plasmid yang mengandung gen HbActin (kontrol positif). Panjang produk PCR dari primer HbActin yang digunakan dalam penelitian ini adalah $195 \mathrm{pb}$.

\section{Seleksi kontrol internal untuk analisis ekspresi gen}

Dalam menentukan ekspresi relatif sebuah gen, hasil dapat bervariasi tergantung pada kondisi biologis sampel (pengaruh jaringan spesifik, atau ekspresi pada waktu tertentu) (Skern et al., 2005). Seleksi kontrol internal sangat penting karena dapat menormalisasi variasi yang terjadi pada ekspresi gen target (Kozera \& Rapacz, 2013). Normalisasi tersebut akan memberikan nilai ekspresi yang terukur secara 
Tabel 1. Sekuen primer 11 gen housekeeping dan enam gen Ethylene Response Factors (ERFs) dari Hevea brasiliensis.

Table 1. Primer sequences of 11 housekeeping and six Ethylene Response Factors (ERFs) genes from Hevea brasiliensis.

\begin{tabular}{|c|c|c|c|c|c|}
\hline \multirow{2}{*}{$\begin{array}{l}\text { Gen / } \\
\text { Genes }\end{array}$} & \multicolumn{2}{|c|}{ Sekuen primer / Primer sequences } & \multirow{2}{*}{$\begin{array}{c}\text { Produk } \\
\text { PCR / } \\
\text { PCR } \\
\text { product } \\
(p b)\end{array}$} & \multirow{2}{*}{$\begin{array}{l}\text { Efisiensi } \\
\text { primer / } \\
\text { Primer } \\
\text { efficiency } \\
(\%)\end{array}$} & \multirow{2}{*}{$\begin{array}{l}\text { Referensi / } \\
\text { Reference }\end{array}$} \\
\hline & Forward $\left(5^{\prime}-3^{\prime}\right)$ & Reverse $\left(5^{\prime}-3^{\prime}\right)$ & & & \\
\hline \multicolumn{6}{|c|}{ 1. Gen housekeeping } \\
\hline HbActin & AGTGTGATGTGGATATCAGG & GGGATGCAAGGATAGATC & 195 & 97.50 & Putranto et al., 2012 \\
\hline HbelF1Aa & GCGTGACTATCAGGACGACAA & CAAGACCTCCAGCAATACCCT & 198 & 97.60 & Li et al., 2011 \\
\hline $\mathrm{HbUBC4}$ & TCCTTATGAGGGCGGAGTC & CAAGAACCGCACTTGAGGAG & 221 & 99.19 & Li et al., 2011 \\
\hline$H b U B C 2 b$ & CGACCAAGTTTTCATTTCGGGTG & AGTCTCTTCTTTGCTGGGGTTG & 219 & 96.90 & Li et al., 2011 \\
\hline$H b U B C 2 a$ & CATTTATGCGGATGGAAGCA & CAGGGGAGTTTGGATTTGGA & 197 & 97.90 & Li et al., 2011 \\
\hline HbYLS8 & CCTCGTCGTCATCCGATTC & CAGGCACCTCAGTGATGTC & 213 & 96.90 & Li et al., 2011 \\
\hline$H b R H 2 b$ & $\begin{array}{l}\text { GAGGTGGATTGGCTAACTGAGAA } \\
\text { G }\end{array}$ & $\begin{array}{l}\text { GTTGAACATCAAGTCCCCGAG } \\
\text { C }\end{array}$ & 215 & 98.90 & Piyatrakul et al., 2012 \\
\hline HbRH8 & TCACAGGGTTGGTAGATCAG & CCAAGCTCTTGCTCAATCC & 209 & 95.80 & Li et al., 2011 \\
\hline$H b \alpha T U B$ & GGTTGGTAGATCAGGCAGGTTTGG & CAACCACAAAAGTGCAATGG & 207 & 95.00 & Duan et al., 2010 \\
\hline$H b 40 S$ & ACAGGCTCATCACCTCCAAG & CAACCACAAAAGTGCAATGG & 211 & 97.00 & Duan et al., 2010 \\
\hline$H b U B I$ & TTATCCAATGCGATCCAACC & CAAGGTCAAGGCTCACCAAT & 214 & 91.00 & Putranto et al., 2012 \\
\hline \multicolumn{6}{|c|}{ 2. Gen-gen Ethylene Response Factors (ERFs) } \\
\hline HbORA47 & TCAAGGATGATGAGGAGTAGCA & GAACAGATGGTTGTGGTGGA & 217 & 100 & Piyatrakul et al., 2012 \\
\hline HbRAP2.3 & AACGTTTCTGGGATTGGAG & TTGGAACCCTAAACACACCA & 208 & 100 & Piyatrakul et al., 2012 \\
\hline HbERF12 & TTCAACGGAGAAGCCTCAG & AGCTCATCGTCAGTCGGTAA & 197 & 100 & Piyatrakul et al., 2012 \\
\hline HbERF3 & CACGCCAGCTACTGGTCTTT & TACCAGCACTAGCACCACCA & 203 & 100 & Piyatrakul et al., 2012 \\
\hline$H b A B R 1$ & CATTGGTGTTGGATGTTAGTGG & ACTCTGACTGGTGGACTCTCCT & 196 & 100 & Piyatrakul et al., 2012 \\
\hline HbRRTF1 & CCTATGATAAGGCGGCGATA & TCAСТTТССТТССССТTТСС & 190 & 97.50 & Piyatrakul et al., 2012 \\
\hline
\end{tabular}

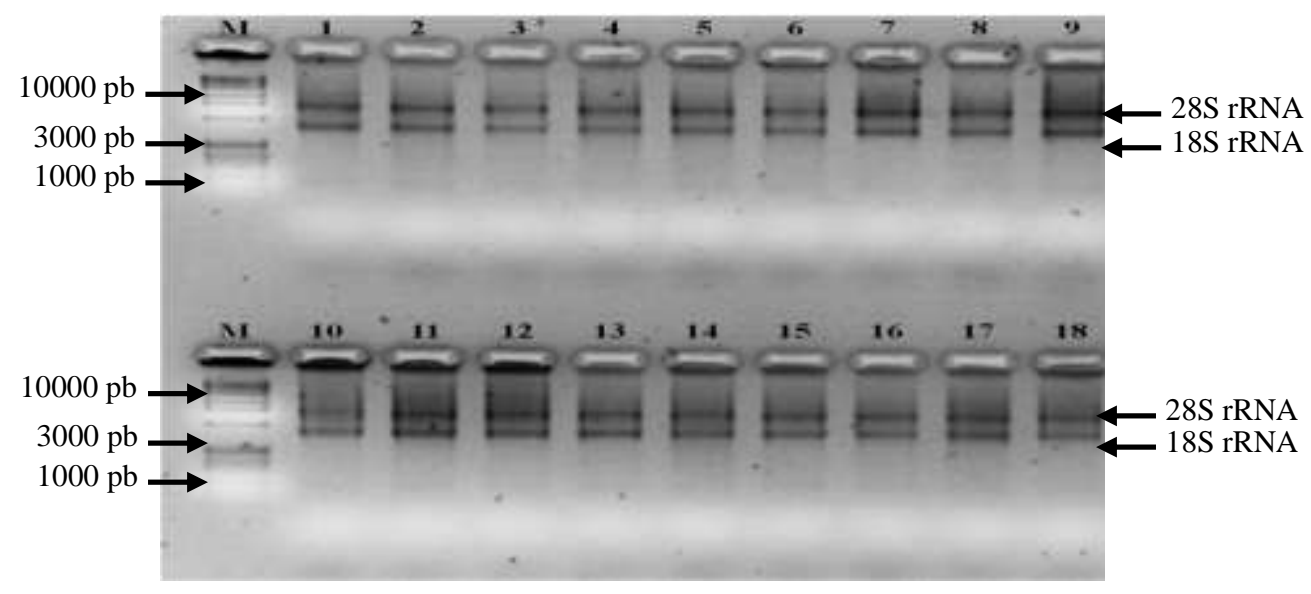

Gambar 1. Profil RNA total hasil isolasi dari lateks tiga klon tanaman karet (PB 260, SP 217, RRIM 600). M : 2-Log DNA ladder. Lajur 1-3 : klon PB 260; tanpa stimulasi ET; dengan tingkat kemurnian 1.79, 1.69, dan 1.77. Lajur 4-6 : klon PB 260; dengan stimulasi ET; dengan tingkat kemurnian 1.71, 1.72, dan 1.75. Lajur 7-9 : klon SP 217; tanpa stimulasi ET; dengan tingkat kemurnian 1.73, 1.73, dan 1.75. Lajur 10-12 : klon SP 217; dengan stimulasi ET, dengan tingkat kemurnian 1.75, 1.76, dan 1.75. Lajur 13-15 : klon RRIM 600; tanpa stimulasi ET; dengan tingkat kemurnian 1.75, 1.72, dan 1.81. Lajur 16-18 : klon RRIM 600; dengan stimulasi ET, dengan tingkat kemurnian $1.76,1.78$, dan 1.74. Konsentrasi RNA dalam tiap sumur adalah $500 \mathrm{ng}$.

Figure 1. Profile of total RNA isolated from latex of three rubber tree clones (PB 260, SP 217, RRIM 600). M : 2-Log DNA ladder. Lane 1-3 : clone PB 260; without ET; with purity level of 1.79, 1.69, and 1.77. Lane 4-6 : clone PB 260; with ET stimulation; with purity level of $1.71,1.72$, and 1.75. Lane 7-9 : clone SP 217; without ET; with purity level of 1.73, 1.73, and 1.75. Lane 10-12 : clone SP 217; with ET stimulation, with purity level of 1.75, 1.76, and 1.75. Lane 13-15 : clone RRIM 600; without ET, with purity level of 1.75, 1.72, and 1.81. Lane 16-18: clone RRIM 600; with ET stimulation; with purity level of 1.76, 1.78, and 1.74. RNA concentration of each well was $500 \mathrm{ng}$. 


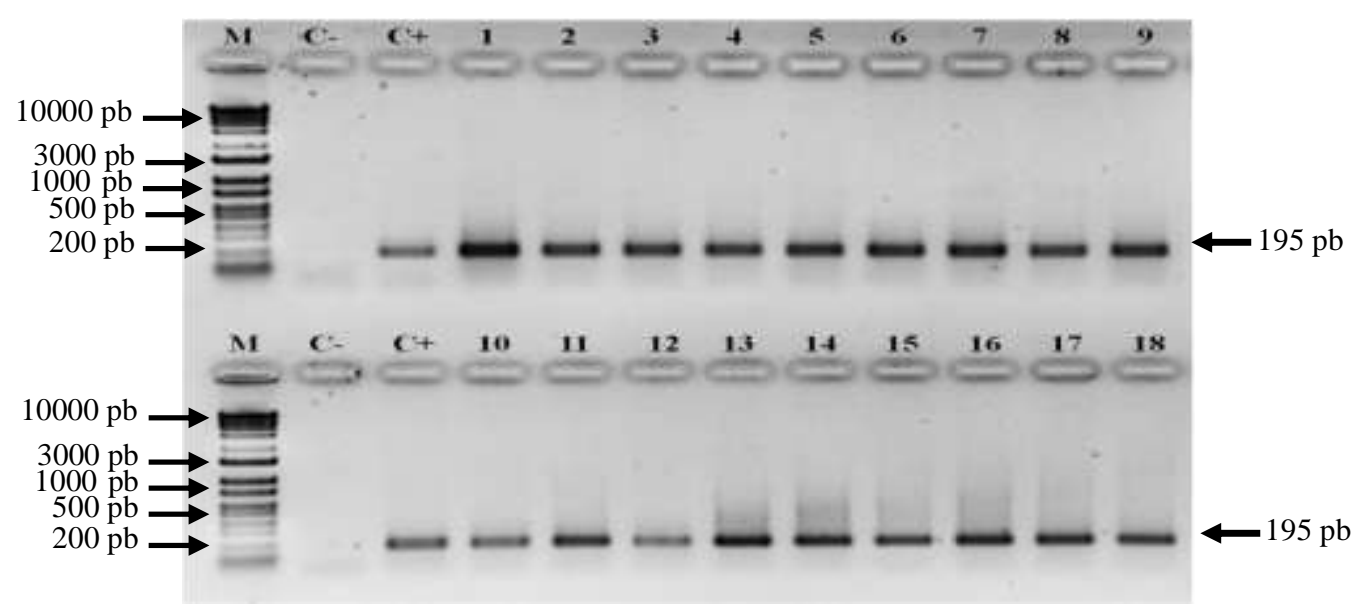

Gambar 2. Profil cDNA dari hasil amplifikasi PCR menggunakan primer standar HbActin. M : 2-Log DNA ladder. C- : kontrol negatif (air bebas nuklease). C+ : kontrol positif (plasmid HbActin). Lajur 1-3 : klon PB 260; tanpa stimulasi ET. Lajur 4-6 : klon PB 260; dengan stimulasi ET. Lajur 7-9 : klon SP 217; tanpa stimulasi ET. Lajur 10-12 : klon SP 217; dengan stimulasi ET. Lajur 13-15 : klon RRIM 600; tanpa stimulasi ET. Lajur 16-18 : klon RRIM 600; dengan stimulasi ET.

Figure 2. Profile of cDNA resulted from PCR amplification using standar primer HbActin. $M: 2-L o g$ DNA ladder. C- : negative control (nuclease free water). $C+$ : positive control (HbActin plasmid). Lane 1-3 : clone PB 260; without ET stimulation. Lane 4-6 : clone PB 260; with ET stimulation. Lane 7-9 : clone SP 217; without ET stimulation. Lane 10-12 : clone SP 217; with ET stimulation. Lane 13-15 : clone RRIM 600; without ET stimulation. Lane 16-18 : clone RRIM 600; with ET stimulation.

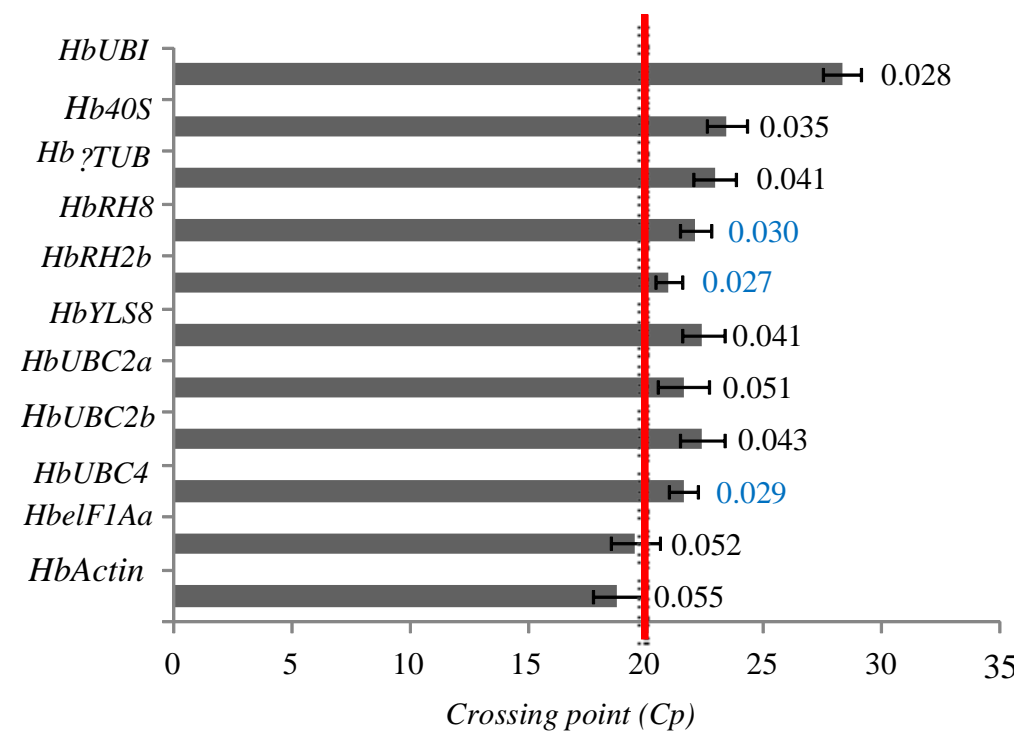

Gambar 3. Seleksi kontrol internal dari gen-gen housekeeping pada $H$. brasiliensis untuk analisis ekspresi menggunakan Real-Time qRT-PCR. Nilai Cp merupakan rata-rata dari 18 sampel cDNA yang digunakan di penelitian ini. Nilai koefisien variansi tercantum di sebelah kanan histogram. Standar deviasi ditunjukkan dengan simbol batang. Batang merah menunjukkan nilai Cp ideal untuk kontrol internal.

Figure 3. Selection of internal control of housekeeping genes from $\mathrm{H}$. brasiliensis for expression analysis using Real-Time qRT-PCR. Cp values were mean of 18 cDNA samples used in this research. Coefficient of variance values were shown on the right side of histogram. Standard deviation was shown in bars. Red bar showed an ideal threshold of $C p$ value for internal control.

relatif terhadap kontrol internal dan mencegah ekstrapolasi data ekspresi (Udvardi et al., 2008). Dengan demikian, gen kandidat untuk marka ekspresi gen dapat ditentukan lebih akurat.

Dari total 11 gen housekeeping, tiga gen yaitu $H b R H 2 b, H b U B C 4$, dan $H b R H 8$ memiliki nilai rata- rata Cp yang diharapkan yaitu diantara 20-25 (20.98, 21.56, dan 22.06) serta koefisien variasi yang rendah $(0.0270,0.0287$, dan 0.0300) dari seluruh sampel yang diuji (Gambar 3). Hasil tersebut menunjukkan bahwa rendahnya variasi $\mathrm{Cp}$ di dalam sampel sesuai dengan kriteria yang diperlukan untuk menjadi 
kontrol internal dalam analisis ekspresi gen. Kontrol internal yang memiliki jumlah transkrip yang relatif stabil sangat ideal digunakan untuk normalisasi ekspresi gen. Terkait hal tersebut, gen $H b R H 2 b$ dipilih sebagai reference gene dalam penelitian ini. Dalam setiap percobaan menggunakan teknik RealTime qPCR, kontrol internal harus selalu divalidasi karena kondisi sampel yang dipastikan bervariasi. Terlebih, reaksi sel pada tingkat molekuler dapat terjadi dalam hitungan detik hingga menit.

Pada beberapa penelitian sebelumnya di tanaman karet, pemilihan kontrol internal yang secara rutin dilakukan untuk setiap analisis ekspresi gen menggunakan Real-Time $q R T-P C R$ memberikan data ekspresi yang lebih akurat dan reliable (Piyatrakul et al., 2012; Piyatrakul et al., 2014; Putranto et al., 2012). Dalam setiap penelitian tersebut, gen $H b R H 2 b$ yang merupakan famili dari $R N A$ helicases $D E A D$ box, memperlihatkan fungsinya sebagai kontrol internal yang stabil.

Ekspresi enam gen HbERFs terhadap stimulasi ethephon pada tiga klon tanaman karet

Penelitian-penelitian sebelumnya melaporkan bahwa gen-gen HbERFs telah digunakan sebagai marka ekspresi gen dalam perkembangan planlet tanaman karet melalui embriogenesis somatik dan dalam respon terhadap stres abiotik pada klon tanaman karet PB 260 (Piyatrakul et al., 2012; Piyatrakul et al., 2014; Putranto et al., Submitted-b). Pada penelitian ini, enam gen $H b E R F s$ terpilih distimulasi dengan ethephon dan ekspresi gennya dianalisis pada tiga klon tanaman karet yang memiliki sistem metabolisme lateks yang berbeda. Pemilihan gen-gen tersebut didasarkan pada tingkat ekspresi tinggi yang diperlihatkan dalam respons terhadap berbagai stres abiotik dan stres penyadapan lateks (Putranto et al., Submitted-b).

Sesuai dengan hipotesis, gen-gen HbERFs tersebut memperlihatkan akumulasi transkrip yang berbeda untuk tiap klon (Gambar 4). Hal tersebut membuktikan bahwa genotip dari klon karet dapat mempengaruhi ekspresi gen-gen kunci HbERFs. Untuk gen HbORA47, akumulasi transkrip tidak berbeda secara signifikan pada dua klon karet PB 260 dan SP 217 yang memiliki metabolisme lateks yang berlawanan. Namun, pengaruh stimulasi ethephon signifikan pada klon RRIM 600. Akumulasi transkrip gen tersebut pada tanaman kontrol klon RRIM 600 adalah sebesar $5.06 \times 10^{-4}$. Sementara itu, perlakuan dengan stimulasi ethephon menghambat ekspresi gen HbORA47 menjadi sebanyak $6.23 \times 10^{-5}(0,12$ kali lebih kecil). Gen HbRAP2.3 memperlihatkan tendensi yang berbeda. Stimulasi ethephon meningkatkan secara signifikan akumulasi transkrip gen tersebut untuk klon PB 260 dan SP 217 sebanyak 10.55 (dari $1.21 \times 10^{-2}$ menjadi $1.28 \times 10^{-1}$ ) dan 9.00 kali (dari $3.79 \times 10^{-3}$ menjadi $3.41 \times 10^{-2}$ ) dibanding tanaman kontrol, secara berurutan. Pola ini tidak diikuti oleh klon RRIM 600 yang tidak memperlihatkan beda nyata ekspresi gen HbRAP2.3 antara tanaman yang diperlakukan dengan stimulasi ethephon dan kontrol menurut analisis statistik. Efek stimulasi ethephon pada gen HbERF12 secara signifikan hanya terlihat pada klon PB 260 dengan peningkatan akumulasi transkrip sebanyak 26.54 kali (dari $5.77 \times 10^{-5}$ menjadi $1.53 \times 10^{-3}$ ). Profil akumulasi transkrip yang sama untuk ketiga klon ditunjukkan oleh gen $H b E R F 3$.

Hasil tersebut dikon-firmasi oleh analisis statistik meskipun akumulasi transkrip gen HbERF3 cukup tinggi pada klon RRIM 600 setelah stimulasi ethephon. Variasi dari ketiga ulangan biologis yang tinggi ditunjukkan oleh nilai deviasi standar yang tinggi, sehingga nilai ekspresi gen menjadi tidak signifikan. Sementara itu, gen $H b A B R l$ terinduksi sangat tinggi dari $1.61 \times 10^{-7}$ menjadi $2.55 \times 10^{-4}$ (1583.85 kali dibanding tanaman kontrol) pada klon RRIM 600. Hasil lain yang menarik adalah bahwa ekspresi gen $H b A B R l$ dengan mengesampingkan efek ethephon memperlihatkan gradien ekspresi dari tiga klon yang diuji. Secara statistik, klon PB 260 memiliki akumulasi transkrip gen $H b A B R I$ yang sangat rendah dibanding SP 217 dan RRIM 600 (Gambar 4). Sementara gen HbRRTF1 memperlihatkan akumulasi transkrip yang secara statistik lebih superior pada klon PB 260 dan RRIM 600 dibanding klon SP 217. Akan tetapi, efek stimulasi ethephon secara signifikan terlihat pada klon SP 217 dengan peningkatan akumulasi transkrip sebanyak 500.77 kali (dari $1 \times 10^{-8}$ menjadi $\left.5.01 \times 10^{-6}\right)$.

Profil tiga klon tanaman karet terhadap perlakuan ethephon dengan menggunakan marka ekspresi gen dari HbERFs

Karakteristik ekspresi gen-gen HbERFs yang berbeda untuk tiap klon memiliki potensi untuk memetakan klon-klon tanaman karet terhadap sebuah sifat atau karakter. Pemetaan tersebut dapat diwujudkan dalam bentuk kode warna yang secara visual dan cepat mampu mengidentifikasi respon molekuler dari klon tanaman karet. Dalam penelitian ini, pemetaan tersebut dicontohkan dalam profil ekspresi tiga klon tanaman karet terhadap respon perlakuan ethephon dengan menggunakan enam marka ekspresi gen (Gambar 5). Klon PB 260 memiliki dua marka ekspresi gen upregulated yaitu HbRAP2.3 dan HbERF12 dari total enam marker ekspresi. Sebagaimana diketahui, klon PB 260 yang memiliki metabolisme aktif termasuk dalam klon tipe quick starter. Klon tipe tersebut mampu memproduksi lateks dalam jumlah tinggi pada tahun-tahun awal penyadapan. Pada klon dengan metabolisme lateks yang tinggi, konsumsi sukrosa sebagai sumber karbon diubah secara cepat menjadi cis-polyisopren 
(partikel karet) melalui jalur fermentatif piruvat. Hal tersebut menunjukkan bahwa kondisi hipoksik (kadar oksigen rendah) di dalam sel latisifer dapat terjadi (Piyatrakul et al., 2014). Gen HbRAP2.3 disinyalir berperan dalam pengaturan homeostasis kadar oksigen di dalam sel latisifer (Piyatrakul et al., 2014).

Ekspresi positif dari gen $H b R A P 2.3$ disinyalir meningkatkan ketahanan sel latisifer dalam kondisi hipoksik sehingga mampu terus menghasilkan lateks. Gen tersebut termasuk di dalam grup ERF-VII yang telah banyak dipelajari pada tanaman model Arabidopsis, dimana fungsi spesifik dalam respon terhadap kadar oksigen rendah dalam sel telah dibuktikan (Bailey-Serres et al., 2012; Licausi et al., 2011). Di sisi lain, ekspresi tinggi dari gen $H b E R F 12$ yang merupakan ERF tipe represor (Putranto et al., Submitted-b), menunjukkan adanya fungsi represi terhadap gen-gen target $H b E R F 12$ yang hingga saat ini belum diketahui pada $H$. brasiliensis. Dalam literatur, faktor transkripsi bertipe represor ini memiliki peran besar di dalam induksi kematian sel terprogram (programmed cell death) (Ogata et al., 2013). Pada tanaman karet, gen tersebut dikaitkan dengan kematian sel dalam kasus penyakit KAS dan berpotensi menjadi marka ekspresi saat tanaman karet terserang penyakit fisiologis tersebut (Putranto et al., Submitted-a).

Disisi lain, klon SP 217 memperlihatkan profil yang berbeda dengan dua marka ekspresi upregulated yaitu HbRAP2.3 dan HbRRTF1. Klon SP 217 dikenal sebagai klon slow starter dan toleran terhadap penyakit KAS (Putranto et al., Submitted-a). Marker ekspresi gen HbRRTF1 merupakan hasil yang menarik untuk klon tersebut. Pada tanaman Arabidopsis, gen AtRRTFl berfungi sebagai master regulator dari homeostasis redox di dalam sel yang telah dibuktikan secara empirik. Gen tersebut menjaga sel dari stres oksidatif yang disebabkan dari kondisi redox yang tidak terkontrol (Khandelwal et al., 2008). Hipotesis yang dapat ditarik pada tanaman karet adalah bahwa HbRRTF1 berpotensi memiliki fungsi yang sama dalam homeostasis redox dan menjadi gen kunci sifat toleran klon tersebut terhadap penyakit KAS.

Untuk klon intermediate seperti RRIM 600, marka ekspresi gen yang terlihat adalah gen HbORA47 dan HbABRl. Yang menarik, gen HbORA47 tampil sebagai marka negatif atau downregulated oleh perlakuan ethephon. Dalam literatur, gen AtORA47 pada Arabidopsis thaliana berperan penting dalam biosintesis asam jasmonat untuk pertahanan tanaman (Pauwels et al. 2008). Hal tersebut menunjukkan adanya pengaturan biosintesis asam jasmonat yang secara potensial menjadi faktor kunci dalam metabolisme dari klon intermediate ini. Perubahan ekspresi HbORA47 saat serangan penyakit KAS dapat diasumsikan dengan terjadinya alterasi biosintesis jasmonat akibat sistem pertahanan tanaman yang lemah. Pengaturan hormon ini rupanya senada dengan gen $H b A B R l$ yang muncul sebagai marka positif atau upregulated. Mutan dari gen abrl pada tanaman Arabidopsis mengakumulasi asam absisat (ABA) yang membuktikan bahwa gen AtABRI merupakan represor dari sinyal ABA (Chao et al. 2014, Pandey et al. 2005). Hingga saat ini, gen $H b A B R 1$ belum dibuktikan secara empiris pada tanaman karet namun diduga memiliki fungsi yang mirip dengan gen ortholognya yaitu AtABRl.

Percobaan ini membuktikan keunggulan dan kegunaan dari marka ekspresi gen untuk mengungkap proses biologis yang terjadi pada organisme tanaman. Marka ekspresi gen dapat menjadi komponen pelengkap dalam proses identifikasi materi tanaman menggunakan marka genetik, seperti DNA fingerprinting. Dengan menggunakan teknologi high debit seperti Real-Time qPCR atau RNA sequencing pada populasi sampel yang besar, identifikasi dan karakterisasi marka ekspresi gen menjadi lebih cepat dan akurat. Pada masa yang akan datang, profiling klonklon karet dengan menggunakan marka ekspresi gen diharapkan dapat ditingkatkan dan diaplikasikan pada populasi klon yang lebih besar.

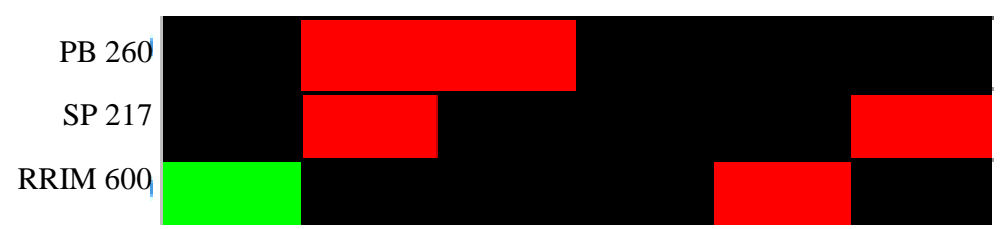

Gambar 5. Profil ekspresi tiga klon tanaman karet (PB 260, SP 217, dan RRIM 600) menggunakan enam marka ekspresi gen terhadap respon perlakuan ethephon. Upregulated marker ditampilkan dengan warna merah sedangkan downregulated marker ditampilkan dengan warna hijau. Data yang tidak signifikan dan gen tidak terekspresi ditampilkan dengan warna hitam.

Figure 5. Expression profile of three rubber tree clones (PB 260, SP 217 and RRIM 600) using six expression marker genes in response to ethephon treatment. Upregulated marker was shown in red colour, while downregulated marker was in green. Non significant data or unexpressed gene $(s)$ were shown in black. 


\section{Kesimpulan}

Dalam penelitian ini telah ditunjukkan penggunaan marka ekspresi gen untuk memetakan karakteristik klon-klon karet terhadap respons perlakuan ethephon. Pemetaan pada level transkripsi tersebut mampu membangun hipotesis tentang proses fisiologis di dalam genotip serta membedakan klon satu dengan yang lainnya.. Kelima gen dari famili gen HbERFs (HbORA47, HbRAP2.3, HbERF12, HbABRl, HbRRTFl) merupakan marka ekspresi yang terbukti penting karena dapat digunakan sebagai pembeda antara tiga klon tanaman karet yang diuji. Gen-gen tersebut memiliki fungsi potensial dalam metabolisme dan ketahanan terhadap cekaman stres yang diduga memiliki korelasi langsung dengan peningkatan produksi lateks.

\section{Ucapan Terima Kasih}

Ucapan terima kasih disampaikan kepada Institut Français de Caoutchouc (IFC), Michelin, Socfinco dan SIPH yang telah mendanai penelitian ini. Ucapan terima kasih juga disampaikan kepada Maryannick Rio atas bantuan teknisnya.

\section{Daftar Pustaka}

Aoki Y, S Takahashi, D Takayama, Y Ogata, N Sakurai, H Suzuki, K Asawatreratanakul, D Wititsuwannakul, $\mathrm{R}$ Wititsuwannakul, D Shibata, $\mathrm{T}$ Koyama \& $\mathrm{T}$ Nakayama (2014) Identification of laticifer-specific genes and their promoter regions from a natural rubber producing plant Hevea brasiliensis. Plant Sci 225, 1-8.

Bailey-Serres J, T Fukao, D J Gibbs, MJ Holdsworth, SC Lee, F Licausi, P Perata, LA CJ Voesenek \& JT van Dongen (2012) Making sense of low oxygen sensing. Trends in Plant Sci 17, 129-138.

Bell GDM, NC Kane, LH Rieseberg \& KL Adams (2013) RNA-Seq analysis of allele-specific expression, hybrid effects, and regulatory divergence in hybrids compared with their parents from natural populations. Genome Biol \& Evolut 5, 1309-1323.

Bustin SA, V Benes, JA Garson, J Hellemans, J Huggett, M Kubista, R Mueller, T Nolan, MW Pfaffl, GL Shipley, J Vandesompele \& CT Wittwer (2009) The MIQE Guidelines: minimum information for publication of quantitative real-time PCR experiments. Clinical Chem 55, 611-622.

Chao WS, M Doğramaci, JV Anderson, ME Foley \& DP Horvath (2014) The resemblance and disparity of gene expression in dormant and non-dormant seeds and crown buds of leafy spurge (Euphorbia esula). BMC Plant Biol 14, 216.

Chen YF, N Etheridge \& GE Schaller (2005) Ethylene signal transduction. Ann Bot 95, 901-15.

Chen YY, LF Wang, LJ Dai, SG Yang \& WM Tian (2012) Characterization of HbEREBP1, a wound-responsive transcription factor gene in laticifers of Hevea brasiliensis Muell. Arg. Mol Biol Rep 39, 3713-9.

Chen YY, LF Wang, SG Yang \& WM Tian (2011) Molecular characterization of HbEREBP2, a jasmonate- responsive transcription factor from Hevea brasiliensis Muell. Arg. African J Biotechnol 10, 97519759.

Duan C, X Argout, V Gébelin, M Summo, JF Dufayard, J Leclercq, K Hadi, P Piyatrakul, J Pirrello, M Rio, A Champion \& P Montoro (2013) Identification of the Hevea brasiliensis AP2/ERF superfamily by RNA sequencing. BMC Genomics 14, 30.

Duan C, M Rio, J Leclercq, F Bonnot, G Oliver \& P Montoro (2010) Gene expression pattern in response to wounding, methyl jasmonate and ethylene in the bark of Hevea brasiliensis. Tree Physiol 30, 1349-59.

Eliathe EAA, KK Edmond, OK Mathurin, LY Justin, NAS Pierre, D Kouadio \& S Abdourahamane (2012) Detection of Hevea brasiliensis clones yield potential and susceptibility to tapping panel dryness in Côte d'Ivoire using the 32 and $35 \mathrm{KDa}$ lutoidic proteins. African J Biotechnol 11, 10200-10206.

Fleige S \& MW Pfaffl (2006) RNA integrity and the effect on the real-time qRT-PCR performance. Mol Aspects of Medicine 27, 126-139.

Ginzinger DG (2002) Gene quantification using real-time quantitative PCR. Experiment Hematol 30, 503-512.

Guo M, MA Rupe, C Zinselmeier, J Habben, BA Bowen \& OS Smith (2004) Allelic Variation of Gene Expression in Maize Hybrids. The Plant Cell Online 16, 17071716.

Khandelwal A, T Elvitigala, B Ghosh \& RS Quatrano (2008) Arabidopsis transcriptome reveals control circuits regulating redox homeostasis and the role of an AP2 transcription factor. Plant Physiol 148, 2050-8.

Kozera B \& M Rapacz (2013) Reference genes in real-time PCR. J Appl Genet 54, 391-406.

Lacote, R., O. Gabla, S. Obouayeba, J. M. Eschbach, F. Rivano, K. Dian \& E. Gohet (2010) Long-term effect of ethylene stimulation on the yield of rubber trees is linked to latex cell biochemistry. Field Crops Research, 115, 94-98.

Li, H., Y. Qin, X. Xiao \& C. Tang (2011a) Screening of valid reference genes for real-time RT-PCR data normalization in Hevea brasiliensis and expression validation of a sucrose transporter gene HbSUT3. Plant Sci, 181, 132-9.

Li, L.-Y., Q. Li, Y.-H. Yu, M. Zhong, L. Yang, Q.-H. Wu, Y.-R. Qiu \& S.-Q. Luo (2011b) A primer design strategy for PCR amplification of GC-rich DNA sequences. Clinical Biochemistry, 44, 692-698.

Licausi, F., M. Kosmacz, D. A. Weits, B. Giuntoli, F. M. Giorgi, L. A. Voesenek, P. Perata \& J. T. van Dongen(2011) Oxygen sensing in plants is mediated by an $\mathrm{N}$-end rule pathway for protein destabilization. Nature, 479, 419-22. 
Miko I (2008) Phenotype variability: penetrance and expressivity. Nature Education 1, 137.

Ogata T, Y Kida, M Tochigi \& Y Matsushita (2013) Analysis of the cell death-inducing ability of the ethylene response factors in group VIII of the AP2/ERF family. Plant Sci 209, 12-23.

Pandey GK, JJ Grant, YH Cheong, BG Kim, L Li \& $S$ Luan (2005) ABR1, an APETALA2-domain transcription factor that functions as a repressor of ABA response in Arabidopsis. Plant Physiol 139, 1185-93.

Pauwels L, K Morreel, E De Witte, F Lammertyn, M Van Montagu, W Boerjan, D Inze \& A Goossens (2008) Mapping methyl jasmonate-mediated transcriptional reprogramming of metabolism and cell cycle progression in cultured Arabidopsis cells. In: Proc Natl Acad Sci U S A, 105, 1380-5.

Piyatrakul P, RA Putranto, F Martin, M Rio, F Dessailly, J Leclercq, JF Dufayard, L Lardet \& P Montoro (2012) Some ethylene biosynthesis and AP2/ERF genes reveal a specific pattern of expression during somatic embryogenesis in Hevea brasiliensis. BMC Plant Biol 12, 244.

Piyatrakul P, M Yang, RA Putranto, J Pirrello, F Dessailly, S Hu, M Summo, K Theeravatanasuk, J Leclercq, Kuswanhadi \& P Montoro (2014) sequence and expression analyses of ethylene response factors highly expressed in latex cells from Hevea brasiliensis. PLoS ONE, 9, e99367.

Putranto RA, E Herlinawati, M Rio, P Piyatrakul, A Clément-Demange, E Gohet, C Sanier, J Pirrello, J Leclercq, Kuswanhadi \& P Montoro (Submitted-a) Regulation of ethylene biosynthesis and signalling pathways, and ROS-scavenging systems in Tapping Panel Dryness of Hevea brasiliensis. Tree Physiol.

Putranto RA, Kuswanhadi, C Duan, T Chaidamsari, M Rio, P Piyatrakul, E Herlinawati, J Pirrello, F Dessailly, J Leclercq, F. Bonnot \& P. Montoro (Submitted-b) ERFs are controlled by multiple harvesting stresses in Hevea brasiliensis. PLOS ONE.

Putranto RA, C Sanier, J Leclercq, C Duan, M Rio, C Jourdan, P Thaler, X Sabau, X Argout \& P Montoro (2012) Differential gene expression in different types of Hevea brasiliensis roots. Plant Sci 183, 149-58.
Qin Y, Y Huang, Y Fang, J Qi \& C Tang (2014) Molecular characterization and expression analysis of the small GTPase ROP members expressed in laticifers of the rubber tree (Hevea brasiliensis). Plant Physiol \& Biochem 74, 193-204.

Rieu I \& SJ Powers (2009) Real-Time quantitative rt-pcr: design, calculations, and statistics. The Plant Cell Online 21, 1031-1033.

Sambrook J, EF Fritsch \& T Maniatis (1989). Molecular Cloning, A Laboratory Manual. CHS Press.

Skern R, P Frost \& F Nilsen (2005) Relative transcript quantification by auantitative PCR: Roughly right or precisely wrong? BMC Mol Biol 6, 10.

Udvardi MK, T Czechowski \& WR Scheible (2008) Eleven golden rules of quantitative RT-PCR. Plant Cell 20, 1736-7.

Wang H, Q Xu, YH Kong, Y Chen, JY Duan, WH Wu \& YF Chen (2014) Arabidopsis WRKY45 Transcription factor activates phosphate transporter 1;1 expression in response to phosphate starvation. Plant Physiol 164, 2020-2029.

Xiao X, C Tang, Y Fang, M Yang, B Zhou, J Qi \& Y Zhang (2014) Structure and expression profile of the sucrose synthase gene family in the rubber tree: indicative of roles in stress response and sucrose utilization in the laticifers. FEBS J 281, 291-305.

Xiong AS, HH Jiang, J Zhuang, RH Peng, XF Jin, B Zhu, F Wang, J Zhang \& QH Yao (2013) Expression and function of a modified AP2/ERF transcription factor from Brassica napus enhances cold tolerance in transgenic Arabidopsis. Mol Biotechnol 53, 198-206.

Zhao S, QT Jiang, J Ma, XW Zhang, QZ Zhao, XY Wang, CS Wang, X Cao, ZX Lu, YL Zheng \& YM Wei (2014) Characterization and expression analysis of WOX5 genes from wheat and its relatives. Gene 537, 63-69.

Zhu J \& Z Zhang (2009) Ethylene stimulation of latex production in Hevea brasiliensis. Plant Signaling \& Behavior, 4, 1072-1074. 